\title{
Bone mineral density status in women with limbus vertebra
}

\section{Limbus vertebra tanılı kadınlarda kemik mineral yoğunluğu \\ Yavuz SAMANCI ${ }^{1}$, M.D., Sadiye Saratas ${ }^{2}$, M.D., Suat Erol CELIIK ${ }^{3}$, M.D.}

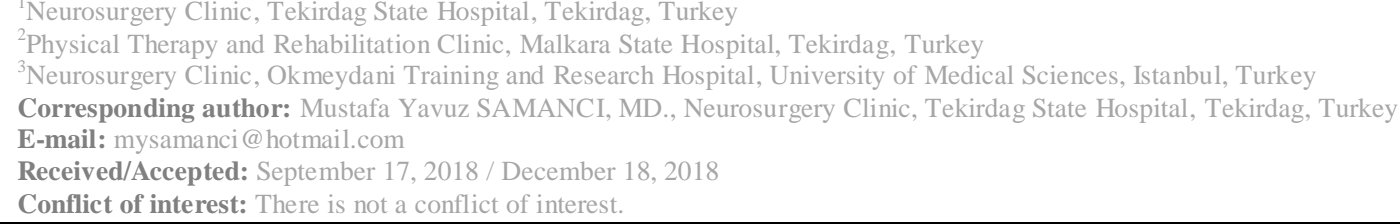

\section{SUMMARY}

Objective: Although genetics and cumulative mechanical stress on an immature skeleton have been proposed to play a role in the development of the limbus vertebra (LV), there is no data concerning the actual degree of bone strength and bone loss in patients with LV.

The aim of this study was to evaluate the bone mineral density (BMD) and the prevalence of osteoporosis in women with LV and compare with age- and body mass index-matched women.

Method: This study was carried out on 171 women (aged 40-49 years) with LV and 190 women without LV. Lumbar spine BMD values were obtained by dual-energy X-ray absorptiometry.

Results: A total of 361 patients were included in the study. The mean total BMD value was significantly lower $(0.876 \pm 0.155$ vs. $0.966 \pm 0.187 \mathrm{~g} / \mathrm{cm} 2, \mathrm{p}<0.0001)$, and the mean T-score value was significantly higher $(-1.6 \pm 1.41$ vs. $-0.8 \pm 1.71, \mathrm{p}<0.0001)$ in patients with LV. Although the frequency of both osteopenia and osteoporosis were higher in patients with $\mathrm{LV}$, the difference reached statistical significance only for osteoporosis $(\mathrm{p}=0.007)$.

Conclusions: Women with LV have lower BMD values and higher osteoporosis rates than age- and BMImatched controls; therefore, osteoporosis should be evaluated in these patients.

Keywords: Bone Mineral Density; Limbus Vertebra; Osteopenia; Osteoporosis; Premenopausal

\section{ÖZET}

Amaç: Her ne kadar genetiğin ve kümülatif mekanik stresin immatür bir iskelet sistemi üzerindeki etkilerinin limbus vertebra (LV) gelişiminde rol oynadığı öne sürülse de, LV tanılı hastalarda kemik yapı ile ilgili bir veri yoktur.

Bu çalışmanın amacı LV tanısı olan kadınlarda kemik mineral yoğunluğunu (KMY) ve osteoporoz prevalansını değerlendirmek ve yaş ve vücut kitle indeksi (VKi) eşleştirilmiş sağlıklı kadınlarla karşılaştırmaktı.

Yöntem: Bu çalışma LV tanılı 171 kadın (40-49 yaş aralığında) ve LV tanısı olmayan 190 kadın üzerinde yapıldı. Lomber omurga KMY değerleri dual enerji X-1şını absorpsiyometrisi ile elde edildi.

Bulgular: Çalışmaya toplam 361 kadın dahil edildi. LV tanılı hastalarda ortalama total KMY değeri istatistiksel olarak anlamlı düşük (sırasıyla $0.876 \pm 0.155$ ve $0.966 \pm 0.187 \mathrm{~g} / \mathrm{cm} 2, \mathrm{p}<0.0001$ ) ve ortalama T-skoru istatistiksel olarak anlamlı yüksek (sırasıyla $-1.6 \pm 1.41$ ve $-0.8 \pm 1.71, \mathrm{p}<0.0001$ ) idi. Her 
osteopeni hem de osteoporoz sıklığı LV tanılı hastalarda daha yüksek olmasına rağmen, bu fark sadece osteoporoz için istatistiksel anlamlılığa ulaştı $(p=0.007)$.

Sonuç: LV tanılı kadınlar, yaş ve VKİ eşleştirilmiş kontrollerden daha düşük KMY değerlerine ve daha yüksek osteoporoz oranlarına sahiptir; bu nedenle bu hastalarda osteoporoz muhakkak araştırılmalıdır.

Anahtar sözcükler: Kemik Mineral Yoğunluğu; Limbus Vertebra; Osteopeni; Osteoporoz; Premenopozal

\section{INTRODUCTION}

Limbus vertebra (LV), a bone deformity caused by an intra-osseous marginal herniation of the nucleus pulposus through a defect through the vertebral endplate and beneath the ring apophysis, was first described by Schmorl ${ }^{1}$ in 1927. The anterior herniation of the nucleus pulposus results in the separation of a smooth triangular bone fragment, which apparently represents the ring apophysis and may ossify separately, and the anterosuperior corner of a vertebral body in the middle lumbar spine is most frequently affected (Figure 1) ${ }^{2}, 3$. Although LV is typically asymptomatic, there is an increasing debate about the clinical significance of the LV as the great majority of reported cases of LV refer to symptomatic patients ${ }^{4}$ and as it is often misdiagnosed as a fracture, which may result in unnecessary invasive procedures.

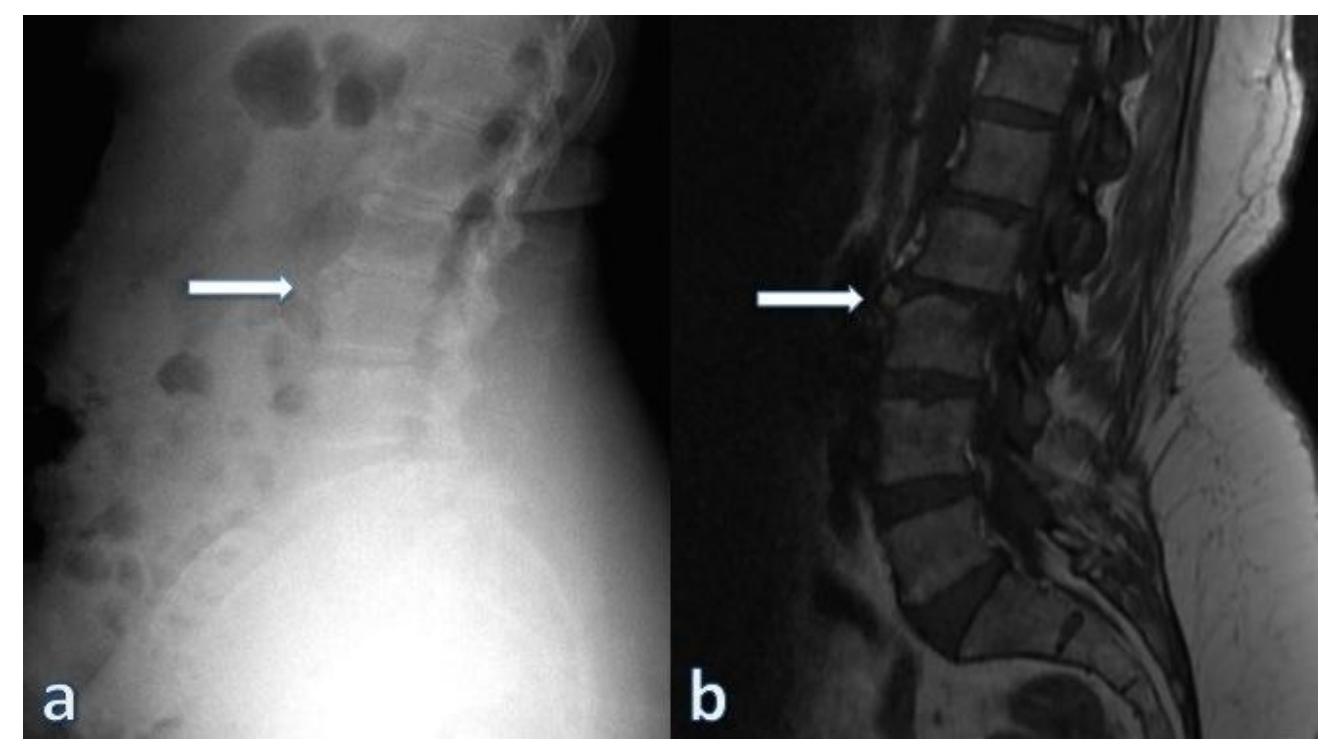

Figure 1. Lateral radiograph (a) and T2-weighted image (b) of the lumbar spine showing anterior limbus vertebra at the superior endplate of the L3 vertebra (white arrows)

Although genetics and cumulative mechanical stress on an immature skeleton have been proposed to play a role in the development of the $\mathrm{LV}^{5,6}$, there is no data concerning the actual degree of bone strength and bone loss in patients with LV.

\section{MATERIAL AND METHODS}

\section{Study subjects}

The current study was based on a retrospective analysis of a consecutive series of 171 premenopausal women who were diagnosed with
The aim of this study was to evaluate bone mineral density (BMD) values at the lumbar spine in 171 premenopausal women with $\mathrm{LV}$ and to compare these results with values obtained from 190 age- and body mass index (BMI)-matched premenopausal women.

LV by X-ray, CT and MR imaging and 190 ageand BMI-matched premenopausal women without LV. All participants attended the neurosurgery outpatient clinic between January 2016 and January 2017 due to low back pain. Patients and controls with the following conditions were 
excluded: (a) postmenopausal women, (b) ages less than 40 and more than 49, (c) patients who were on medications affecting the bone metabolism, including glucocorticoids, diuretics, vitamin D supplements, and bisphosphonate hormone replacement therapy for at least 6 months before the evaluation, (d) patients with medical conditions affecting bone metabolism, including malignancy, chronic infectious or inflammatory diseases, systemic gastrointestinal, renal, respiratory diseases, and thyroid disorders, (e) patients with previously diagnosed osteoporosis, (f) limbus vertebra located outside the lumbar vertebrae, (g) cigarette smoking, (h) alcohol consumption, (i) patients with severe physical inactivity, (j) regular exercise (2-3 days/week), (k) personal history of trauma, and (1) radiographic contrast material (barium) use within the past 7 days or nuclear medicine studies within the past 3 days before DXA scans.

Patients were divided into subgroups, and the BMD values and prevalence of osteopenia/osteoporosis were compared between the groups.

\section{Clinical data}

The data was collected from the patients' medical records, regarding (a) age, (b) weight, (c) height, (d) BMI, (e) smoking status, (f) alcohol consumption, (g) exercise, (h) personal history of trauma, (i) the level of limbus vertebra, and (j) DXA results.

\section{DXA scans}

A total of 361 patients were included in this study. The mean age, height, weight, and BMI of the study population and patient subgroups are given in Table 1. The differences between patient groups regarding basic characteristics were not statistically significant. The mean total BMD value was significantly lower, and the mean Tscore value was significantly higher in patients
Lumbar spine BMD values were obtained from the first to the fourth lumbar vertebral body by DXA using Discovery Wi DXA scanner (Hologic ${ }^{\circledR}$, Bedford, MA, USA). The DXA scans of the lumbar spine provided data for each lumbar vertebra separately (L1, L2, L3, and L4) as well as for the total lumbar spine (L1-L4). The BMD values were expressed as grams of mineral content per square centimeters of bone area $(\mathrm{g} / \mathrm{cm} 2)$ and the results were reported as T scores (standard deviation above or below values for young healthy population). According to the World Health Organization (WHO) classification system, osteoporosis is defined as any $\mathrm{T}$-score lower than -2.5 , osteopenia as any $\mathrm{T}$-score between -2.5 and -1.0 , and normal bone density as any T-scores equal to or greater than -1.0.

\section{Statistical analysis}

Results were reported as means with standard deviations or frequencies with $95 \%$ confidence intervals. Continuous variables between patients, and between patients and controls were compared with use of paired-samples t-test and independentsample t-test. The prevalence of osteoporosis in each group was compared by $\chi^{2}$ test. All statistical analyses were performed using SPSS 21.0 software (SPSS Inc., Chicago, IL, USA), and $\mathrm{p}$ values $<0.05$ were considered statistically significant.

\section{RESULTS}

with LV. Although the frequency of both osteopenia and osteoporosis were higher in patients with $\mathrm{LV}$, the difference reached statistical significance only for osteoporosis $(p=0.007)$ (Table 1). 
Table 1. Basic and densitometric characteristics of the patient groups

\begin{tabular}{|c|c|c|c|c|}
\hline & $\begin{array}{l}\text { Total subjects } \\
\qquad(\mathrm{n}=361)\end{array}$ & $\begin{array}{l}\text { Patients with LV } \\
(n=171)\end{array}$ & $\begin{array}{l}\text { Patients without } \\
\text { LV (n=190) }\end{array}$ & $\mathbf{p}$ \\
\hline Age, years & $44.3 \pm 2.82$ & $44.2 \pm 2.86$ & $44.4 \pm 2.78$ & 0.485 \\
\hline Height, $\mathrm{cm}$ & $158.4 \pm 6.03$ & $158.1 \pm 6.44$ & $158.7 \pm 5.63$ & 0.314 \\
\hline Weight, kg & $72.2 \pm 13.79$ & $71.9 \pm 13.50$ & $72.5 \pm 14.07$ & 0.558 \\
\hline Body mass index, $\mathrm{kg} / \mathrm{m}^{2}$ & $28.8 \pm 5.41$ & $28.8 \pm 5.41$ & $28.8 \pm 5.42$ & 0.840 \\
\hline BMD-Total $\left(\mathrm{g} / \mathrm{cm}^{2}\right)$ & $0.924 \pm 0.178$ & $0.876 \pm 0.155$ & $0.966 \pm 0.187$ & $<0.0001$ \\
\hline T-score Total & $-1.1 \pm 1.62$ & $-1.6 \pm 1.41$ & $-0.8 \pm 1.71$ & $<0.0001$ \\
\hline Osteopenia (\%) & 33.8 & 35.1 & 32.6 & 0.657 \\
\hline Osteoporosis (\%) & 24.4 & 31.0 & 18.4 & 0.007 \\
\hline
\end{tabular}

The fourth lumbar vertebra was the most commonly involved vertebra. The BMD values and $\mathrm{T}$-scores of the patients with $\mathrm{LV}$ according to the involved level are given in Table 2. Comparison between BMD values and T-scores of lumbar vertebrae with the corresponding level at controls revealed significant differences only in L4 vertebra $(\mathrm{p}=0.004$ and $\mathrm{p}=0.003$, respectively). Osteopenia was more common in patients with L3 LV and osteoporosis was more common in patients with L2 LV, however, these differences were insignificant (Table 3 ).

Table 2. Densitometric characteristics of the study population according to the level of limbus vertebra

\begin{tabular}{lccc}
\hline & $\begin{array}{c}\text { Patients with LV } \\
(\mathbf{n}=\mathbf{1 7 1})\end{array}$ & $\begin{array}{c}\text { Patients without LV } \\
(\mathbf{n}=\mathbf{1 9 0})\end{array}$ & p \\
\hline BMD-Lumbar 2, g/cm & $0.853 \pm 0.155(\mathrm{n}=12)$ & $0.960 \pm 0.188$ & 0.223 \\
T-score-Lumbar 2 & $-1.6 \pm 1.42(\mathrm{n}=12)$ & $-0.7 \pm 1.70$ & 0.322 \\
BMD-Lumbar 3, g/cm & $0.936 \pm 0.178(\mathrm{n}=35)$ & $0.999 \pm 0.200$ & 0.505 \\
T-score-Lumbar 3 & $-1.3 \pm 1.61(\mathrm{n}=35)$ & $-0.8 \pm 1.82$ & 0.585 \\
BMD-Lumbar 4, g/cm & $0.896 \pm 0.164$ & $0.991 \pm 0.225$ & $\mathbf{0 . 0 0 4}$ \\
& $(\mathrm{n}=124)$ & & \\
T-score-Lumbar 4 & $-1.5 \pm 1.49(\mathrm{n}=124)$ & $-0.6 \pm 2.06$ & $\mathbf{0 . 0 0 3}$ \\
\hline
\end{tabular}

LV: limbus vertebra, BMD: bone mineral density, g: gram, cm: centimeter 
Table 3. The frequency of osteopenia and osteoporosis of the study population according to the level of limbus vertebra

\begin{tabular}{lcccc}
\hline & Lumbar 2 & Lumbar & Lumbar & $\mathbf{p}$ \\
& $(\mathbf{n = 1 2})$ & $\mathbf{3}(\mathbf{n}=\mathbf{3 5})$ & $\mathbf{4}(\mathbf{n = 1 2 4})$ & \\
\hline Osteopenia (\%) & 25.0 & 37.1 & 35.5 & 0.737 \\
Osteoporosis (\%) & 50.0 & 25.7 & 30.6 & 0.288 \\
\hline
\end{tabular}

\section{DISCUSSION}

To date, no studies were conducted on BMD status in patients with LV. In the present study, the BMD status in premenopausal women with ALV was analyzed and results were compared with age and BMI-matched premenopausal Turkish women. This study showed that the mean total BMD value was significantly lower and the mean T-score value was significantly higher in patients with LV compared with the values of patients without LV.

Several authors have proposed that LV results from the intrabody herniation of disk material ${ }^{2,7}$, whereas others have suggested that traction through the attached soft tissue causes injury to the anterior part of the vertebral ring apophysis ${ }^{8}$. This condition was commonly described in adolescents and later in adults from 30 to 50 years $2,9,10$. Similar to previous studies, the mean age in the present study was $44.3 \pm 2.82$ years. The anterosuperior corner of a vertebral body in the middle lumbar spine is most frequently affected, whereas the inferior and posterior margin and other regions are less frequently found ${ }^{2,} 3^{3}$. Consistent with the literature, LV was observed mostly in L4 vertebra, followed by L3 vertebra in the present study.

The bone mass is acquired between the ages of 20 to 30 , and the peak bone mass is reached at the age of 35 years, greatly decreasing during the perimenopausal period ${ }^{11}$. The rate of bone loss in lumbar vertebrae decreases after menopause and stabilizes in women at 60-69 years of age ${ }^{12}$. For this reason, it is expected that BMD levels in younger patients will be higher. There was a small negative correlation $(\mathrm{r}=-0.154, \mathrm{p}=0.033)$ between age and mean total BMD value in patients without $\mathrm{LV}$, however, a significant correlation could not be detected in patients with $\mathrm{LV}(\mathrm{r}=-0.093, \mathrm{p}=0.226)$.
In the study by Paker et al. on 205 healthy women aged between $20-79,{ }^{13}$ a mean BMD value was found to be $1.132 \pm 0.09 \mathrm{~g} / \mathrm{cm}^{2}$ and a mean Tscore as $0.47 \pm 0.79$ in 35 patients in the $40-49$ years age group. Even with significantly higher BMI values in patients with $L V$ and without $L V$, in the present study $(26.5 \pm 4.1$ vs. $28.8 \pm 5.41$, p $=0.006$ and $26.5 \pm 4.1$ vs. $28.8 \pm 5.42, \mathrm{p}=$ 0.0055 , respectively), the mean BMD values were significantly lower in both groups $(\mathrm{p}<0.0001$, for both) compared to the findings of Paker et al. ${ }^{13}$. The significantly lower mean BMD values found in the present study makes a reliable comparison with respect to the results by Paker et al. ${ }^{13}$, as the effect of geographic differences with capacity to influence over bone mass for both studies were minimal. In another study in 347 women and 119 men (age range 20-80 years), Manisali et al. ${ }^{14}$ detected a mean BMD value of $0.930 \pm 0.11$ $\mathrm{g} / \mathrm{cm}^{2}$ in 91 female patients in the 40-49 years age group. Compared with this value, the mean BMD values were significantly lower in both groups $(\mathrm{p}$ $=0.0013$ in patients with $\mathrm{LV}$ and $\mathrm{p}=0.0442$ in patients without LV) in the present study.

The frequency of osteoporosis in Turkey has been reported to range between 12-20\% 15-17. The overall frequency of osteoporosis was 24.4 in the study population and the frequency of osteoporosis was $31.0 \%$ in patients with LV, indicating higher prevalence of osteoporosis in patients with LV than that of the control. Therefore, women at 40-49 years of age with LV should be evaluated for osteoporosis and this may help to prevent future osteoporotic fractures, as spine fractures were associated with an increased mortality ${ }^{18}$. 


\section{CONCLUSION}

The data of the present study suggest that osteoporosis should be evaluated and managed by screening BMD in patients with LV. Nevertheless, it seems necessary to design large longitudinal prospective studies in order to characterize definitively the bone loss accounting in patients with LV.

\section{Acknowledgments}

The authors thank the subjects whose participation made this study possible.

\section{REFERENCES}

1. Scmorl G. Die pathologische Anatomie der Wirbelsaule. Verhandlungen der Deutschen Orthopadeschen Gesellschaft 1926; 21:3-41.

2. Ghelman B and Freiberger RH. The limbus vertebra: an anterior disc herniation demonstrated by discography. AJR Am $J$ Roentgenol 1976; 127: 854-5. DOI: 10.2214/ajr.127.5.854.

3. Yagan R. CT diagnosis of limbus vertebra. J Comput Assist Tomogr 1984; 8: 14951.

4. Acosta V, Pariente E, Lara M, Pini SF, Rueda-Gotor J. Limbus Vertebra and Chronic Low Back Pain. Journal of Family Medicine 2016; 3: 1048.

5. Koyama K, Nakazato $\mathrm{K}$, Min $\mathrm{S}$, et al. COL11A1 gene is associated with limbus vertebra in gymnasts. Int J Sports Med 2012; 33: 586-90. DOI: 10.1055/s-0031-1299752.

6. Bennett DL, Nassar L and DeLano MC. Lumbar spine MRI in the elite-level female gymnast with low back pain. Skeletal Radiol 2006; 35: 503-9. DOI: 10.1007/s00256-006-00837.

7. Hellstrom M, Jacobsson B, Sward L and Peterson L. Radiologic abnormalities of the thoraco-lumbar spine in athletes. Acta Radiol 1990; 31: 127-32.

8. Sward L, Hellstrom M, Jacobsson B and Karlsson L. Vertebral ring apophysis injury in athletes. Is the etiology different in the thoracic and lumbar spine? Am J Sports Med 1993; 21: $841-5$.

9. Jones DM, Tearse DS, el-Khoury GY, Kathol MH and Brandser EA. Radiographic abnormalities of the lumbar spine in college football players. A comparative analysis. Am J Sports Med 1999; 27: 335-38.

10. Kolt GS and Kirkby RJ. Epidemiology of injury in elite and subelite female gymnasts: a comparison of retrospective and prospective findings. Br J Sports Med 1999; 33: 312-8.

11. Cosman F, de Beur SJ, LeBoff MS, et al. Clinician's Guide to Prevention and Treatment of Osteoporosis. Osteoporos Int 2014; 25: 2359-81. DOI: 10.1007/s00198-014-2794-2.

12. Arlot ME, Sornay-Rendu E, Garnero P, Vey-Marty B and Delmas PD. Apparent pre- and postmenopausal bone loss evaluated by DXA at different skeletal sites in women: the OFELY cohort. J Bone Miner Res 1997; 12: 683-90. DOI: 10.1359/jbmr.1997.12.4.683.

13. Paker N, Erbil M, Otlu Z, Soy D, Uysal E. Bone mineral density in healthy Turkish women. Journal für Mineralstoffwechsel \& Muskuloskelettale Erkrankungen 2005; 12: 73-76.

14. Manisali M, Ozaksoy D, Yilmaz E, et al. Bone mineral density reference values in the normal female and male population of Izmir, Turkey. Eur Radiol 2003; 13: 157-62. DOI: 10.1007/s00330-002-1371-9.

15. Alkan B, Fidan F, Tosun A, Ardicoglu Ö. Fiziksel Tıp ve Rehabilitasyon Polikliniğimize Başvuran Hastalarda Osteoporoz İnsidansı. Türk Osteoporoz Dergisi 2011; 17: 10-13.

16. Tuzun S, Eskiyurt N, Akarirmak U, et al. Incidence of hip fracture and prevalence of osteoporosis in Turkey: the FRACTURK study. Osteoporos Int 2012; 23: 949-55. DOI: 10.1007/s00198-011-1655-5.

17. Aslan A, Karakoyun O, Guler E, et al. [Evaluation of bone mineral density, osteoporosis prevalence and regional risk factors in Turkish women living in Kastamonu: KASTURKOS study]. Eklem Hastalik Cerrahisi 2012; 23: 62-7.

18. Johnell O, Kanis JA, Oden A, et al. Mortality after osteoporotic fractures. Osteoporos Int 2004; 15: 38-42. DOI: 10.1007/s00198-003$1490-4$. 